\title{
Influence of Monetary Policy on The Credit Supply To Small and Medium Scale Enterprises In Nigeria (1993 -2018)
}

Claudius Olaoye Awoniyi

Afe Babalola University

Adebayo Tunbosun Ogundipe ( $\nabla$ bosundipe@abuad.edu.ng )

Afe Babalola University https://orcid.org/0000-0003-3720-822X

\section{Research}

Keywords: Monetary policy, Monetary policy rate, lending rate, inflation, liquidity ratio

Posted Date: September 13th, 2021

DOl: https://doi.org/10.21203/rs.3.rs-885734/v1

License: (c) (1) This work is licensed under a Creative Commons Attribution 4.0 International License.

Read Full License 


\title{
INFLUENCE OF MONETARY POLICY ON THE CREDIT SUPPLY TO SMALL AND MEDIUM SCALE ENTERPRISES IN NIGERIA (1993 -2018)
}

\author{
Dr. Claudius Olaoye Awoniyi \\ Department of Banking and Finance, Afe Babalola University, Ado Ekiti, Nigeria \\ laoyejohn@gmail.com \\ Dr. Adebayo Tunbosun Ogundipe \\ Director of Information Technology Afe Babalola University, Ado Ekiti, Nigeria \\ bosundipe@abuad.edu.ng
}

\begin{abstract}
The study examined the effect of monetary policy on credit supply to small and medium scale enterprises (SMEs) in Nigeria covering a temporal scope 1993 to 2018. It was modelled by using ratio of credit to SMEs to total credit (CSTC) as dependent variable while monetary policy rate (MPR), liquidity ratio ( $L Q R)$, lending rate ( $L D R)$ and inflation (INF) were the explanatory variables. Secondary data were sourced from CBN Statistical Bulletin and the estimation was done using Auto regressive distributed lag (ARDL). The study found that monetary policy has negative and insignificant effects on credit supply to SMEs in the long run while in the short run, monetary policy has though insignificant positive but indirectly a significant positive effect through lending rate on credit available to SMEs. The implication is that, as MPR changes its effects are transmitted through lending rates of commercial banks to SMEs. Hence, the study concluded that monetary policy significantly and heterogeneously impacts on the credit supply to $S M E s$ indirectly through lending rate in Nigeria. It was recommended among others that as the Central Bank of Nigeria continues to implement monetary policy in Nigeria, caution should be taken so that such decisions won't be detrimental to businesses such as SMEs. In addition, MPR should be further reviewed downward in order to encourage SMEs from assessing more funds in Nigeria. Likewise, a pool of long-term funds should be created By Central Bank of Nigeria to bridge the financing gap of SMEs in Nigeria.
\end{abstract}

Keywords: Monetary policy, Monetary policy rate, lending rate, inflation, liquidity ratio

\section{Introduction}

Existence of several studies on small and medium scale enterprises within and outside Nigeria have shown its importance and the reasons why many nations have carved out different 
policies and strategies to enhance its performance. Globally, SMEs have been found contributing greatly to the economic growth and development of a nation. Majorly, it has been acknowledged that SMEs help in providing strong solution to socio economic problems that ravaged most economies of the world, some of which are, provision of employment, reduction of poverty, development of the private sector, generates incomes, increase standard of living especially helps in improving a nation GDP per capita, etc. As a result, Gbandi and Amissah (2014) and Onugu (2005) have emphasized the fact that, performance of small and medium scale enterprises could rapidly contributes to achievement of sustainable development goals, as most of the objectives or goals of SDGs are within what can be solved efficiently by SMEs provided there is conducive environment and attention of government towards them.

However, despite this fact, SMEs are still faced with lots of challenges which prevents them from contributing efficiently to the economy. From the existing studies, the challenges facing SME s ranges from inadequate financing and difficulties in accessing funds from money deposit banks, strict bank conditions that must be met before accessing credit, strict conditions for listing at the stock exchange, low demand of the SMEs product, lack of domestic market and majorly the business environment which comprises the economic and regulatory, technology, competitive, social and global environments. All these affect the performance of SMEs in one way or the other. Especially the regulatory environment which consists of monetary and fiscal policies and other policies of government that may be implemented due to the dictates of the economy.

In actual fact, government policies, especially monetary policy, have a great effect on the performance of SMEs. Since monetary policy is targeted towards stabilizing the economy, by maintaining balance between the money supply, cost, credit and the economy through the use of both quantitative and qualitative instruments, SMEs may be affected when such policies are not friendly. For example, SMEs need funds to stimulate their business but accessing it might be difficult when the government through the central bank pursues a contractionary monetary policy where money supply is reduced and interest rate is high. In such a situation, some SMEs would find it difficult to obtain such funds at a high cost and consequently, it would affect the expansion of business and as well as its contribution to economic development. On the other 
hand, if the funds are opted for at such high cost, it would surely affect the profit of the business or repayment ability of the business. This was argued by Udoh, Gbande and Acha (2018) as he said "despite continuous implementation of these policies, some of the challenges that faces SMEs still remained such as high interest rate, high rate of inflation and unstable foreign exchange rate"

The effect of monetary policy could also be seen from the credit ditched out by deposit money banks to small and medium scale enterprises over the year which is represented by the ratio of commercial bank credit to SMEs as a percentage to total credit. As it can be seen from fig. 1, this percentage has been declining rather than increasing. Within the period 1992 to 2018, it could be seen that the percentage declined seriously from the highest point of $27.04 \%$ in 1992 to $0.29 \%$ in 2018 . To worsen the situation the prime interest rate has remained 2 digit, fluctuating between $29.80 \%$ in 1992 to $16.94 \%$ in 2018. Unfortunately, this is a big setback for SMEs in Nigeria as well as the growth of the economy because without adequate funds and easy access, no single business can strive.

Figure 1

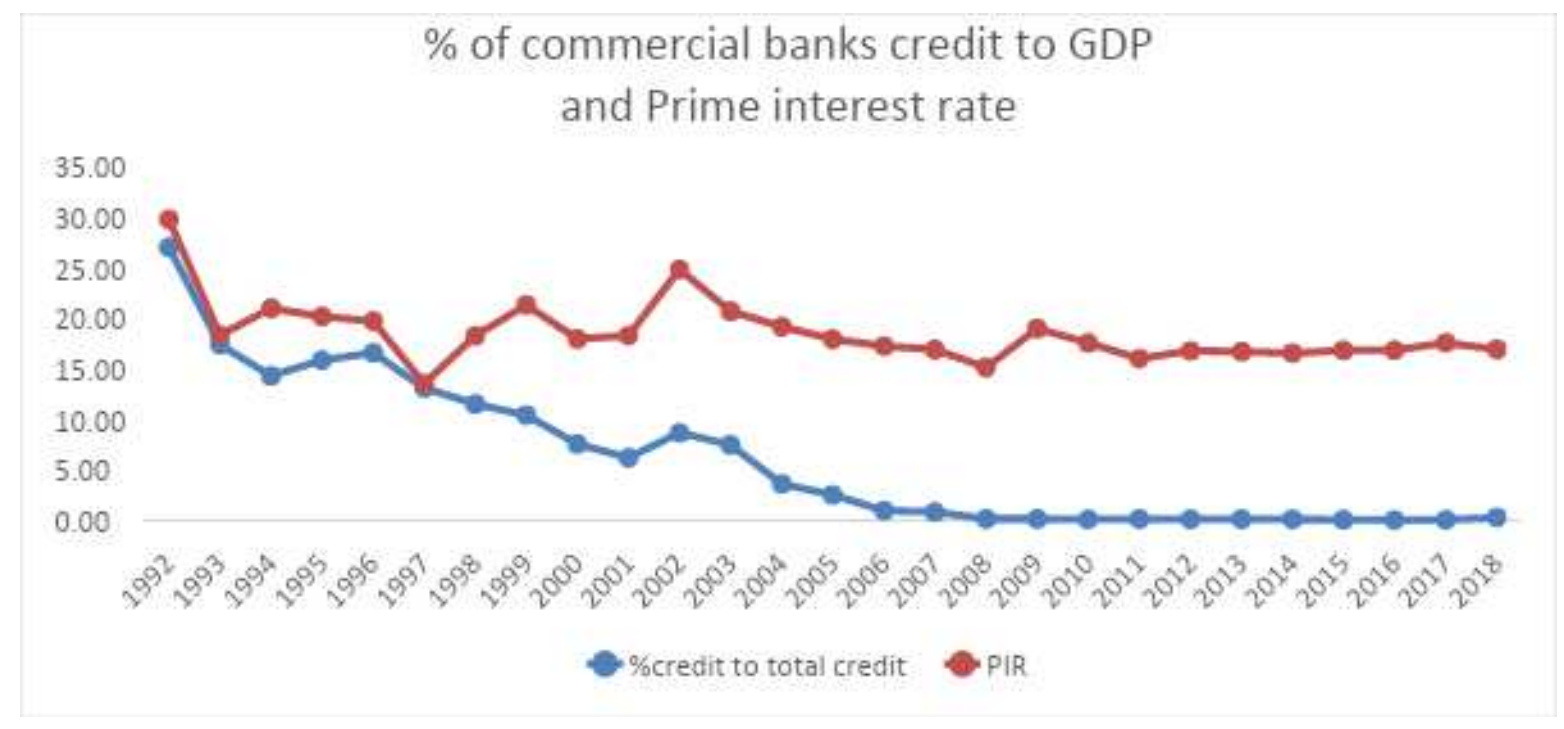

\section{Source: CBN Statistical Bulletin of various editions}

However, governments all over the world, including Nigeria have acknowledged some of these problems facing SMEs and as such, have come up with different policy measures to solve 
credit needs of SMEs. Some of these policies as given by Mordi, Anyanwu, Adebusuyi, Odey, Amoo, Mbutor, Adebayo and Akpan, (2014) are

"bilateral arrangements and establishment of various institutions and programmes such as establishment of early development banks like Nigerian Industrial Development Bank (1962), Small Scale Industries Credit Scheme (1971), the Nigerian Bank for Commerce and Industry (1973) and the Bank of Industry (2001). Also, they emphasized that, from 2002, the Central Bank of Nigeria intervened by establishing several schemes including the Refinancing and Rediscounting Facility, N200 Billion Restructuring/Refinancing Scheme, N200 Billion Commercial Agricultural Credit Scheme (2009) and the Nigerian Incentive-Based Risk Sharing System for Agricultural Lending (2011). They further said that, government and the CBN, other institutions like the World Bank and Nigerian Bankers' Committee have come up with SME support schemes such as the US\$41 million World Bank SME I Loan Scheme (1984), World Bank US\$270 million SME II Loan Scheme (1990) and the Small and Medium Enterprises Equity Investment Scheme (2001) by the Bankers' Committee". Despite these, the contribution of SMEs to economic growth in Nigeria is still very inadequate.

In the last two decades, several studies have emerged focusing on the challenges of SMES in Nigeria such as , Motilewa, Ogbari and Aka, (2015), Yahaya, Geidama and Usman, (2016) and contribution of SMEs to economic growth as well as the extent of the effect of SMEs on social economic development in Nigeria some of which are Oyeniran Oladipo \& Ajayi, 2015; Imoisi and Jumbo, (2015), Aminu Adamu and Ibrahim, (2018). Their findings have made it clear to understand the problems of SMEs and how much contribution of SMEs is to economic growth and socio-economic development in Nigeria, however, there is death of empirical studies on the effect of monetary policy on the credit supplied by banks especially commercial banks to SMEs in Nigeria, except the study of, Nto, Mbanasor and Osuala (2012). Hence, this study is concerned on the effect of monetary policy on supply of credit to small and medium scale enterprises in Nigeria covering the period from 1992 to 2018. 


\section{Literature Review}

Folawewo and Osinubi (2006) defined monetary policy "as the specific actions taken by monetary authority to regulate the value, supply and cost of money in the economy with a view to achieving predetermined macroeconomic goals. This means, to achieve predetermined economic goals, such as achievement of economic growth, price stability, favorable balance of payment and low level of unemployment, CBN embarks on monetary controls. In doing this, it classifies money into Narrow Money $\left(\mathrm{M}_{1}\right)$ and Broad Money $\left(\mathrm{M}_{2}\right) \cdot \mathrm{M}_{1}$ is made up of currency in circulation with the non-bank public; and demand deposits (current accounts in the banks). This category of money represents money used for daily transactions and short-term monetary needs. The second which is the $\mathrm{M}_{2}$ (broad money) consists of narrow money, savings, time deposits as well as foreign currency-denominated deposits. This measures the total volume of money supply in the economy through which liquidity and inflation issues are tackled by the CBN (Ogechukwu, 2009).

Monetary policy is one of the prime economic management tools that governments use to shape economic performance. Uniamikogbo \& Enoma, (2001) posited that monetary policy is quicker at resolving economic shocks. Deliberating on the impact of monetary policy on private sector investment, Kahn (2010) observed that monetary policy objectives are concerned with the management of multiple monetary targets among them price stability, promotion of growth, achieving full employment, smoothing the business cycle, preventing financial crises, stabilizing long-term interest rates and the real exchange rate. He further states that these objectives are obviously not consistent with each other, as the preference of monetary policy objectives is anchored upon the weights assigned by monetary authorities or country priorities. Experience shows that emphasis is usually placed on maintaining price stability or ensuring low inflation rates.

Ayodeji and Ajala (2019) posited that there are two major control mechanisms of monetary policy used by Central Banks at any point in time and this control mechanism are usually referred to as tools/instruments of monetary policy and they have effects on the proximate or ultimate targets. Monetary instruments can be direct or indirect. The direct instruments include aggregate credit ceilings, deposit ceiling, exchange control, restriction on the 
placement of public deposit, special deposits and stabilization securities while indirect instruments include Open Market Operation (OMO), cash reserve requirement, Monetary policy rate. In addition, Imoughele and Ismaila, (2014) explained that "monetary policy has vital roles in the short-run i.e. it is used for countercyclical output stabilization, while in the long run, it is used to achieve the macroeconomic goals of full employment, price stability, rapid economic growth and balance of payments equilibrium".

The need to regulate money supply arises from the observed direct relationship that exists between it and economic activities. This means that when the supply of money rises above required levels or falls below required levels, economic activities are negatively affected owing to inflation or illiquidity as the case may be; and this can hamper growth of industries. In its attempt to control the money supply to achieve desired levels, the CBN uses several instruments which can be subdivided into two, direct control of credits and indirect control of credit. The direct control of credit consists of interest on loans, amount and direction of credit etc while indirect control of credit are open market operation, reserve requirements and the use of discount windows (Ayodeji \& Ajala, 2019). Although Mustar, (2002) emphasized that there is no clear evidence that these strategies have engendered the expansion and development of the small and medium scale business sector or if it has been taken into consideration.

One of the means of stimulating SMEs performance is through monetary policy and this has its root from macroeconomic theory. Monetary policy is expected to affect the real sector of the economy through interest rate movements that has effect in altering the cost of capital and investment in the productive sector. To support this, Mordi et al. (2014) also emphasized that monetary policy is one of the macroeconomic management tools used to influence outcomes in the real economy to its desired direction. The basic goals of monetary policy are the promotion of stable prices, sustainable output and employment and these are achieved through several channels such as interest rates, credit, asset prices through exchange rates, equity and housing prices (Mishkin, 2007).

In implementing monetary policy, Alexander, Balino \& Enoch, (1996) explained that the central bank can act directly, using its regulatory powers, or indirectly, using its influence on money market conditions as the issuer of reserve money. The term "direct" here refers to the 
one-to-one correspondence between the instrument either direct or indirect instruments and the policy objective. Direct instruments operate by setting or limiting either prices such as interest rates through regulations, while indirect instruments act through the market, in the first instance, adjusting the underlying demand for, and supply of, bank reserve.Using indirect instruments, the central bank can determine the supply of reserve money. Strictly speaking, the central bank can determine the supply of reserve money in the long run only under a fully flexible exchange rate regime. Even under a pegged or managed exchange rate regime, however, central bank transactions affect reserve money, at least in the short run and these transactions as well affect banks' liquidity positions, which results in adjustments of interbank interest, money market rate, and bank loan and deposit interest rates which equate the demand for, and the supply of money(Alexander, Balino \& Enoch, 1996).

\section{Small and Medium Scale Enterprises (SMEs)}

The concept of small and medium scale enterprises differs from country to country; most especially, the concept differs whether it is developed or developing countries. This means, what may constitute SMEs in one country may be regarded as a medium scale enterprise in another country depending on the rate of their development and vice versa. However, in most literature, small and medium scale enterprises are defined based on very different modalities such as capital outlay, number of employees, sales turnover, fixed capital investment, available plant and machinery, market share and the level of development. To support this, Ogechukwu, (2009) said the trend in developed nations like the United States of America (USA), Britain and other European countries is to categorize small and medium scale enterprises in terms of turnover and number of employees.

According to Gbandi and Amissah, (2014) SMEs are defined based on an asset base (excluding land) of between N5 million and N500 million and labour force of between 11 and 300 belongs to the SME sub-sector. from this. SMEs are defined in terms of asset base and labour force. Another form of definition as given by Small and Medium Enterprises Equity Investment Scheme (SMEEIS) defined SMEs as businesses with turnover of less than N100 million, asset base of N1.5 billion (excluding land and working capital) with no lower or upper limit of staff (Gbandi \& Amissah, 2014). The Central Bank of Nigeria Monetary Policy Circular 
No. 22 of 1996 defined small or medium scale business enterprises as any manufacturing or service enterprise whose business turnover does not exceed N500,000 (including land and working capital) and or the annual turn-over did not exceed N5 million.

In the 1990 budget, Federal government of Nigeria (CBN) also defined small/medium scale enterprises, for the purpose of commercial bank loans as those enterprises with annual turnover not exceeding N500,000 and for Merchant Bank loans, those enterprises with capital investments not exceeding N2m excluding cost of land, and between 11 and 100 employees (Asa-Afiana 2003). While large scale industries are those with investment of over N200m, excluding land but including working capital and a workforce of over 300 people.

\section{Interest rate and SMEs Credit}

Interest rate is the cost of funds on loans extended by banks to their customers. Banks have different types of customers some of which are corporate, individual, infant etc. Small and medium scale enterprises that would need financial assistance from banks are expected to own a corporate or enterprise account as the holders of such accounts are regarded as bank customers in the eyes of the law. Banks grant financial assistance to current holders of which SMEs are one and when such loan is granted, there is a cost attached which is called cost of funds or interest on loans. Customers are to pay interest for using banks money and this interest is controlled by the apex bank through a monetary policy instrument called monetary policy rate.

Monetary policy rate is the baseline rate or prime lending rate or minimum rediscount rate that affects all other rates in an economy (Ayodeji and Ajala, 2018). By implication, when the Central Bank of Nigeria increases this rate, it affects the lending rate of the banks by shifting it upwards and this will trigger action of the financial institutions by adding a margin to this rate to get their own lending rate for profitability. This is mostly used when the central bank is pursuing monetary tight policy or contractionary monetary policy to reduce the volume of money in an economy so as to reduce inflation. Furthermore, the monetary policy rate can be reduced by the apex bank which would trigger the financial institutions to add a margin downward to the rate in order to reduce the lending rate. This is called expansionary monetary policy and its effect is to increase the volume of money in circulation with the aim of increasing economic activities. This means the process of tightening and relaxing monetary policy rate affects the volume of 
credit to be accessed by customers and ability of banks to give out credit. All these affects the growth of small and medium scale enterprises

To support the above, Duru and Kehinde (2012) emphasized that dependence of SMEs on banks for credit rendered them more vulnerable as the shocks in the banking system could have significant impact on the supply of credit to SMEs. They gave example of some of the small and medium scale enterprises in manufacturing sector in Nigeria that remained stagnated due to their inability meet up with the cost of funds while those that were able to meet up with the interest rate on loans could not assessed the loans because of other conditions such as collateral security, certificate of occupancy, in adequate track records etc. The effect of this is less contribution of the sector to economic growth.

Berger and Udell(2012) also opined that, small and medium scale enterprises encounter problems in assessing finance because most of them relied on banks rather than capital markets to source the finance needed and as a result, any shock in the banking system can have a significant impact on the supply of credit to small business. They further said that, "small firms are subject to funding problems in equilibrium and these problems may be exacerbated during periods of disequilibrium in financial markets".

Therefore, as SMEs relied on financial institutions (commercial banks, merchant banks, development banks, mortgaged banks, microfinance banks etc) to raise funds to undertake productive investment, expand their businesses and acquire the latest technology that can boost their operations and growth of the nation, these vision may be affected by decision of the apex bank especially, when monetary policy rate moves upward to affect lending rate which could rendered most SMEs to remain incapable of assessing bank's loans and as well it would reduce the credit availability of banks.

\section{Theoretical Framework}

This study adopted its theoretical framework, Keynesian IS-LM Model. It was developed by John Hicks in 1937 and later extended by Alvin Hansen. The model is a macroeconomic tool used in explaining the relationship between interest rates and asset market or better still between money market and goods market. The IS in the model means investment - Savings while LM 
means Liquidity preference money supply. IS-LM. The interest rate therefore links the markets by influencing demand for investment and real money balances. This theory was also used in the work of Ayodeji and Ajala (2018), they explained that, the traditional Keynesian IS-LM model is used to show how changes in the monetary policy instruments, especially the MPR causes exogenous shift in monetary aggregates which affect investment and consumption and later causes changes in output and prices. They further explained that "nexus between the goods market (IS curve) and the money market (LM curve) is influenced by the rate of interest, so that any shock or variability occasioned by rate of interest in one market will affect the other market". Relating this to the study at hand, it explained that, the most channel through which monetary policy transmits the effect of its policy is through monetary policy rate. By expansion of MPR, SMEs have access to funds to improve their business but when it is contractionary, this affects SMEs from accessing funds and as well affects their level of productivity and efficiency.

\section{Empirical Review}

Udoh, Gbande and Acha (2018) investigated the impact of monetary policy on growth of SMEs in Nigeria from 1986 to 2016. The study specified using SMEs output as the dependent variable to proxy growth of SMEs while interest rate, exchange rate and inflation rate as independent variables to proxy monetary policy. Secondary data were sourced from CBN Statistical Bulletin and estimated using Johansen co-integration and Error Correction Model (ECM). The study found a slight significant effect of interest rate on growth of SMEs in Nigeria, but no significant effect was found from exchange rate and inflation on the growth of SMEs in Nigeria.

Akinyemi and Adejumo (2018) investigated the effects of government policies on entrepreneurship activities in emerging economies, Sub-Sahara African economies in perspectives. Survey research design was employed and primary data were sourced majorly from Nigeria and South Africa through a semi structured questionnaire to a total 1200 respondents. Data were analyzed using descriptive statistics and inferential statistics. Also, Principal Component Analysis (PCA) was used to identify the most favorable government policy in each entrepreneurship phase. The study showed variations in the policy implementation approaches of 
both economies. Further findings also revealed that the impact of government policies on entrepreneurship phases differ in both countries.

Kolawole and Lucky (2018) carried out a study on the impact of monetary policy on SMEs small and medium scale enterprises in Nigeria spanning from the first quarter of 1992 to the last quarter of 2016. Commercial banks loans to SMEs was the dependent variable while money supply, interest rate, inflation and exchange rate were used as proxy for monetary policy. Secondary data were sourced majorly from CBN Statistical Bulletin and estimated using johansen co-integration and Error Correction Model (ECM) techniques. The study revealed that interest rate has a positive and significant impact on small and medium scale enterprises performance in Nigeria. Further findings also showed that inflation rate has a significant but negative impact on SMEs performance in Nigeria while on the other hand, money supply and exchange rate were found to be insignificant in impacting SMEs performance.

Akawu, Charles and Olarenwaju (2018) studied the impact of government support on small and medium scale enterprises development in Nasarawa State, using Keffi local government as a case study. Primary data were sourced using semi-structured questionnaires from the population of 558 SMEs such as traders, business centers and GSM repairs, of which 126 were selected. Data sourced were analyzed using a regression method. The study revealed that government capacity building programmes, provision of financial support by government, provision of infrastructural support programs significantly impacted on the development of SMEs in the study area.

Isola and Mesagan (2018) examined the effect of monetary policy on the performance of small and medium scale enterprises in three Africa countries such as Nigeria, Ghana and Gambia covering a period from 1981 to 2016. Output of small and medium scale enterprises was used as the dependent variable while exchange rate, inflation, interest rate and credit to the private sector were the proxies for independent variables. Data in respect of the proxies were sourced from CBN Statistical Bulletin and estimated using regression analysis. The study revealed that monetary policy in the three countries have been unfavorable to the SMEs growth as most of the variables impacted negatively on SMEs outputs. 
Ayodeji and Ajala (2019) researched market based monetary policy instruments and industrial growth in Nigeria covering 1993 to 2016. Dependent variables were measured by industrial growth and market based monetary policy instruments were measured by monetary policy rate, open market operation and liquidity ratio. Obtaining secondary data from CBN Statistical Bulletin and estimating using Auto regressive distributed lag, the study found a long-run relationship between market-based monetary policy instruments and industrial growth in Nigeria. Further findings showed that industrial growth significantly responded to own innovations and impulses from all the three market-based monetary policy instruments signifying heterogenous significant effects of market-based monetary policy instruments on industrial growth in Nigeria

Biljana and Tamara (2013) studied the effectiveness of monetary policy on the performance of SMEs in Serbia over a period 2003 to 2012. The study specified gross domestic product as the dependent variable while narrow money, broad money, government revenue, government expenditure and budget deficits as proxies for both monetary and fiscal policies. Sourcing secondary data from National Bank of Serbia and the Statistical Office of the Republic of Serbia and by employing Johansen co-integration and regression analysis, the study showed that monetary policy is more effective in stimulating SMEs.

Ezeji and Michael (2013) investigated the impact of monetary policy on the economic growth in Nigeria covering a period 1990-2010. Gross domestic product was the proxy for dependent variables while minimum rediscount rate (MRR), interest rate (IR), liquidity ratio (LR), corporate income tax (CIT) and federal budget (FB) were the independent variables. secondary data were sourced in respect to the proxies from CBN Statistical Bulletin and estimated using johansen cointegration and VAR model. The study revealed that monetary policy measures have significant and positive influence on the level of growth of SMEs in Nigeria.

Chingarande (2013) examined the impact of monetary and fiscal policies on the activities of SMEs in Zimbabwe for the period 1981 to 1998. Gross national income was the dependent variable while M2, real government expenditure and real exports were the independent variables. secondary data were relied upon which was sourced from Central Statistical Office (CSO) Quarterly Digest of Statistics, Reserve Bank of Zimbabwe Quarterly Economic and Statistical 
Review and by employing a modified St Louis equation, co-integration and error correction approach on data collected the study found that monetary policy influence is relatively stronger in enhancing the activities of SMEs and suggested that monetary policy can be relied on as a successful macroeconomic stabilization tool in Zimbabwe.

Nto, Mbanasor and Osuala (2012) studied the influence of monetary policy variables on loan supply to small and medium scale enterprises in Nigeria for a period 1995 to 2010. The study specified using credit supply to SMEs by banks as the dependent variable while cash reserve ratio, prevailing interest rate on savings, liquidity ratio and lending rate as monetary policy variables. by adopting fully modified ordinary least square method, the study revealed that, interest rate and liquidity ratio significantly influence the supply of credit to SMEs, however, it was further revealed that while interest rate has negative influence while liquidity ratio has positive influence on credit supplied to SMEs in Nigeria

Younus (2012) investigated the relative importance of monetary policy to the growth of SMEs in Bangladesh from 2000 to 2010. Broad money supply (M2) has been used as a proxy for money while GDP growth at constant prices is used as a proxy for the growth of SMEs. Estimating using econometric techniques such as correlation, granger causality test, co-integration and vector error correction approach, the results showed that monetary policy has significant and positive impact on the growth of SMEs in Bangladesh with varying degree and the outcomes of the study demonstrates that monetary policy has relatively stronger impact than that of fiscal policy in altering the growth of SMEs in Bangladesh

Sanni, Amusa and Agbeyangi (2011) empirically investigated the use of fiscal policy and monetary policy in controlling the economic activities of SMEs in Nigeria for the period from 1960 to 2010. Exchange rate and money supply were used as proxy for monetary policy while the growth of GDP through businesses is used as proxy for the performance of SMEs. Using the Error Correction Mechanism (ECM) method of analysis, the findings showed monetary policy instruments exert more influence on economic activities of SMEs and concluded that a proper mix of the policies may enhance a better growth of SMEs.

Jawaid, Arif and Naeemullah (2010) examined a comparative analysis of monetary policy and fiscal policies on economic growth in Pakistan from 1981 to 2008, using annual time series 
data. Gross domestic product was the proxy for economic growth, money supply as proxy for monetary policy and fiscal balance as proxy for fiscal policy. Relying on secondary data and estimating the proxies using co-integration and regression techniques, the study showed that both monetary and fiscal policy impacted significantly and positively on economic growth. However, by comparing both, the coefficient of monetary policy is much greater than fiscal policy which implies that monetary policy is more concerned with economic growth than fiscal policy in Pakistan.

Ajisafe and Folorunso (2002) examined the relative effectiveness of monetary and fiscal policies in macroeconomic management in Nigeria for the period 1970-1998. $M_{1}$ and $M_{2}$ as monetary policy proxies, government revenue receipts, government expenditure, and government budget deficit as proxies for fiscal policy and gross domestic product was the proxy for economic growth. secondary data were sourced and estimated by employing co-integration and error correction modelling techniques. The study found that monetary policy exerts a great impact on economic activities in Nigeria.

\section{Methodology}

The study focused on monetary policy and also credit supplied by commercial banks to small and medium scale enterprises in Nigeria and it covered the period from 1992 to 2018. The study employed model from Nto et al. (2014) which stated that, $\mathrm{CSUUP}=\mathrm{f}(\mathrm{CRR}, \mathrm{ITR}, \mathrm{LR}, \mathrm{LDR})$

The above model explains that credit supplied to small and medium scale enterprises over the period is a function of cash reserve ratio, savings interest rate, liquidity ratio, and lending rate. This model is adapted with little modification. Hence, credit supplied to SMEs is replaced by the percentage of credit supplied to total credit, while monetary policy rate and inflation are incorporated into the model. the model for the study is therefore stated as

$\mathrm{CSTC}=f(\mathrm{MPR}, \mathrm{LDR}, \mathrm{LQR}, \mathrm{INF})$

In a linearized form, the model is stated as

$\mathrm{CSTC}=\delta \mathrm{o}+\delta_{1} \mathrm{MPR}+\delta_{2} \mathrm{LDR}+\delta_{3} \mathrm{LQR}+\delta_{4} \mathrm{INF}+\mathrm{U}$

Estimating using Auto regressive distributed lag, the model is re-stated as follows 
$\Delta C S T C_{t}=\delta_{0}+\sum_{i=1}^{n} \delta_{1 i} \Delta M P R_{t}+\sum_{i=1}^{n} \delta_{2 i} \Delta L D R_{t}+\sum_{i=1}^{n} \delta_{3 i} \Delta L Q R_{t}+\sum_{i=1}^{n} \delta_{4 i} \Delta I N F_{t}++\delta_{5} C S T C_{t-i}+\delta_{6} M P R_{t-i}+\delta_{7} L D R$ $+\vartheta_{t}$.

Where

$\delta \mathrm{o}=$ Constant term, $\mathrm{CSTC}=$ Credit supplied to SMEs as percentage of total credit, MPR $=$ Monetary policy rate, $\mathrm{LDR}=$ lending rate, $\mathrm{LQR}=$ liquidity ratio $\mathrm{INF}=$ Inflation, $\mathrm{U}=$ error term, $\delta_{1:} \delta_{2:} \delta_{3:} \delta_{4}$ are short run coefficients and $\delta_{5} \delta_{6} \delta_{7} \delta_{8} \delta_{9}=$ are long run coefficients of the explanatory variables.

\section{Sources and Collection of Data}

Data for this study are purely secondary data and it was obtained from CBN Statistical Bulletin of various editions

\section{Estimation Technique}

The estimation of the parameters is done using auto regressive distributed lag (ARDL) after the number of co-integration relations was established. Some other diagnostic tests such as the autocorrelation test and Jarque - Bera test were also conducted to determine the presence of autocorrelation.

\section{Analysis and Interpretation}

The study employed Augmented Dickey Fuller (ADF) unit root to ascertain the stationarity of the variables. The result obtained suggested that variables are integrated of difference order. MPR and LDR were stationary at level I(0), hence they need not be differenced before estimation. On the other hand, CSTC, LQR and INF were non-stationary at level. However, when tested at second difference, it was found that they became stationary at first difference I(1), this means these variables need to be differentiated before estimation. This implies that variables are integrated of different order and this stands as the basis for using auto regressive distributed order. 
Table 1: Summary of Augmented Dickey Fuller

\begin{tabular}{|c|c|c|c|c|}
\hline Variables & $\begin{array}{l}\text { Critical } \\
\text { Value/Prob }\end{array}$ & (a) $1^{\text {st }}$ Diff & (a) $2^{\text {nd }}$ Diff & Integration \\
\hline CSTC & $\begin{array}{r}\text { Test } \\
\text { Prob }\end{array}$ & $\begin{array}{c}-2.0966 \\
0.2475\end{array}$ & $\begin{array}{c}-4.7164 \\
0.0010\end{array}$ & 1(1) \\
\hline MPR & $\begin{array}{l}\text { Test } \\
\text { Prob }\end{array}$ & $\begin{array}{r}-4.3727 \\
0.0022\end{array}$ & N/A & $1(0)$ \\
\hline LDR & $\begin{array}{l}\text { Test } \\
\text { Prob }\end{array}$ & $\begin{array}{r}3.9443 \\
0.0060\end{array}$ & N/A & $1(0)$ \\
\hline LQR & $\begin{array}{l}\text { Test } \\
\text { Prob }\end{array}$ & $\begin{array}{c}2.5651 \\
0.1132\end{array}$ & $\begin{array}{c}-5.2019 \\
0.0003\end{array}$ & $\mathrm{I}(1)$ \\
\hline INF & $\begin{array}{l}\text { Test } \\
\text { Prob }\end{array}$ & $\begin{array}{l}-2.4611 \\
0.1385\end{array}$ & $\begin{array}{l}-6.6340 \\
0.0000\end{array}$ & 1(1) \\
\hline
\end{tabular}

Source: Authors Computation from EViews, 9

\section{Auto Regressive Distributed Lag Cointegration}

Table 2 showed ARDL cointegration between monetary policy and credit supply to small and medium scale enterprises. The result revealed that F-statistics of the Wald test of 9.36 is greater than the Nasaran lower bound 2.86 and upper bound 4.01. This indicates that there exists a long run relationship between monetary policy and credit supply to SMEs.

Table 2: ARDL Cointegration

\begin{tabular}{|c|c|c|}
\hline Test Statistic & Value & $\mathrm{k}$ \\
\hline F-statistic & 9.367783 & 4 \\
\hline \multicolumn{3}{|c|}{ Critical Value Bounds } \\
\hline Significance & 10 Bound & I1 Bound \\
\hline $10 \%$ & 2.45 & 3.52 \\
\hline $5 \%$ & 2.86 & 4.01 \\
\hline $2.50 \%$ & 3.25 & 4.49 \\
\hline $1 \%$ & 3.74 & 5.06 \\
\hline
\end{tabular}

\section{Source: Authors Computation from EViews, 9}

Table 3 presented lag order selection which is one of the major pre conditions for estimating auto regressive distributed lag. The result revealed that lag 2 would be selected using Akaike Information criteria (AIC). This implies that, estimation would be done using lag order two as it shows the least in the column 
Table 3: VAR Lag Order Selection Order

\begin{tabular}{|c|c|c|c|c|c|c|}
\hline Lag & LogL & LR & FPE & AIC & SC & HQ \\
\hline 0 & -34.7159 & NA & 1.864010 & 3.453557 & 3.700403 & 3.515638 \\
\hline 1 & -34.64152 & 0.109952 & 2.030967 & 3.534046 & 3.830261 & 3.608543 \\
\hline 2 & -30.28228 & $6.065036^{*}$ & $1.528021^{*}$ & $3.241937^{*}$ & $3.587523^{*}$ & $3.328851^{*}$ \\
\hline
\end{tabular}

\section{Source: Authors Computation from EViews, 9}

The long run estimates between monetary policy and credit supply to SMEs is presented in Table 4. It was revealed that the coefficients of MPR of -0.0167, LQR of -0.028 and LQR of 0.0426 have negative effects on credit supply to small and medium scale enterprises while INF of 0.0559 has positive effect on credit supply to SMEs. Furthermore, the significance of these variables showed that at 5\% level of significance, none of them is significant. This implies that a unit increase in monetary policy instruments such as MPR, LQR and LDR would have a reduction effect on the credit supply by banks to small and medium scale enterprises while a unit increase in inflation would have an increased effect on credit supply to SMEs. Therefore, the result emphasized that monetary policy in the long run would have an adverse effect on the credit supply to SMEs

Table 4: Effects of Long run relationship between Monetary policy and Credit supply to SMEs

\begin{tabular}{|c|r|r|r|r|}
\hline \multicolumn{7}{|c|}{ Long Run Coefficients } \\
\hline Variable & Coefficient & Std. Error & t-Statistic & Prob. \\
\hline MPR & -0.016751 & 0.08054 & -0.207983 & 0.839 \\
\hline DLQR & -0.028633 & 0.03205 & -0.893388 & 0.3908 \\
\hline LDR & -0.042642 & 0.102214 & -0.417182 & 0.6846 \\
\hline DINF & 0.055991 & 0.039611 & 1.413536 & 0.1852 \\
\hline C & 0.478744 & 1.951115 & 0.245369 & 0.8107 \\
\hline
\end{tabular}

Source: Authors Computation from EViews, 9

Table 5 presents results for the short run relationship between monetary policy and credit supply to SMEs. The result showed that the coefficients of MPR of 0.0974 and LDR of 0.2830 have a positive effect on credit supply to SMEs while LQR of -0.006 and INF of -0.051 have a negative effect on credit supply to SMEs. Checking the significance of the variables, findings 
revealed that LDR and INF have values less than 5\% which indicates that they have significant impact on credit supply to SMEs. The implication is that a unit increase in MPR and LDR would bring about a positive impact on supply of credit to SMEs while a unit increase in LQR and INF would have a reducing effect on credit supply to SMEs. In addition, the speed of adjustment where short run dynamics converge to the long run, that is, Ecm(-1) of -1.124 was rightly signed and the p-value of 0.0002 was highly significant. This implies that the discrepancies in the short run are incorporated into the long run and corrected at $124 \%$ annually.

The coefficient of determination $\left(\mathrm{R}^{2}\right)$ revealed that, $85.99 \%$ variation in dependent variable which is proxy by ratio of credit to SMEs is explained or accounted for by MPR, LQR, LDR and INF while $14.01 \%$ is accounted for by the variable not captured in the model. This is confirmed by the adjusted $\mathrm{R}^{2}$ of $71.99 \%$ which shows the true behaviours of the dependent variable according to the number of the explanatory variables. The F-statistic of 6.1426 is greater than the tabulated F-Statistics of 2.40 and the P-value (0.0027) is highly significant at $5 \%$. This implies that the model is good and confirms that monetary policy has a significant effect on credit supply to SMEs. More importantly, the result of the Durbin Watson test of 1.89 is very close to the benchmark of 2 which indicates that variables in the series are free from serial autocorrelation. From the analysis, the study therefore makes a general submission that monetary policy has a significant impact indirectly through lending rate on credit supply to SMEs only in the short run.

Table 5: Effects of Short run relationship between Monetary policy and Credit supply to SMEs

\begin{tabular}{|c|r|r|r|r|}
\hline \multicolumn{7}{|c|}{ Cointegrating Form } & Prob. \\
\hline Variable & Coefficient & Std. Error & t-Statistic & 0.3843 \\
\hline $\mathrm{D}(\mathrm{MPR})$ & 0.097485 & 0.107582 & 0.906144 & 0.8144 \\
\hline $\mathrm{D}(\mathrm{DLQR})$ & -0.006094 & 0.025341 & -0.240489 & 0.0095 \\
\hline $\mathrm{D}(\mathrm{LDR})$ & 0.229461 & 0.073171 & 3.135944 & 0.0422 \\
\hline $\mathrm{D}(\mathrm{LDR}(-1))$ & 0.283022 & 0.123169 & 2.297838 & 0.5738 \\
\hline $\mathrm{D}(\mathrm{DINF})$ & -0.018661 & 0.032188 & -0.579733 & 0.0257 \\
\hline $\mathrm{D}(\mathrm{DINF}(-1))$ & -0.051617 & 0.020029 & -2.577137 & 0.0002 \\
\hline CointEq(-1) & -1.124698 & 0.199519 & -5.637045 & D.W=1.69 \\
\hline$R^{2}=0.8599$ & Adj-R ${ }^{2}=0.7199$ & F-stat=6.1426 & Prob=0.0027 & \\
\hline
\end{tabular}

Source: Authors Computation from EViews, 9 


\section{Testing for Residual Diagnostics}

Table 6 presents diagnostic checks results and it indicates that the model does not suffer from any of the residual problems such as Serial Correlation, Heteroskedasticity, and the residual is normally distributed.

Table 6: Diagnostics Checks on the Residuals

\begin{tabular}{|c|c|c|c|}
\hline \multicolumn{3}{|c|}{ Breusch-Godfrey Serial Correlation LM Test: } & \multirow[b]{2}{*}{0.5283} \\
\hline F-statistic & 0.6854 & Prob. F(2,9) & \\
\hline \multicolumn{4}{|c|}{ Heteroskedasticity Test: Breusch-Pagan-Godfrey } \\
\hline F-statistic & 0.2946 & Prob. F(11,11) & 0.59729 \\
\hline Jarque-bera & 3.2668 & rob & 0.1952 \\
\hline
\end{tabular}

Source: Authors Computation from EViews, 9

\section{Summary of Findings}

The study has critiqued the effect of monetary policy on the credit supply to small and medium-scale enterprises in Nigeria. It relied on data from CBN Statistical bulletin of which ratio of commercial banks credit to SMEs to total credit the dependent variable while monetary policy rate, liquidity ratio, lending rate and inflation were the explanatory variables covering 1993 to 2018. Using auto regressive distributed lag, findings showed that monetary policy has insignificant negative effects on credit supply to SMEs in the long run while in the short run, monetary policy has significant positive effects through lending rate on credit supply to SMEs. This shows that monetary policy effects on SMEs is through bank lending which means when MPR increases, the effect passes through banking institutions in the form of cost of funds called lending rate to affect small and medium-scale enterprises. However, the a priori expectation of liquidity ratio negates this study because, when liquidity ratio of banks increases, this is supposed to increase credit supply to SMEs, unfortunately in the long and short run, the results were negative. The implication is that, despite the liquidity positions of banks, SMEs were not favoured to assess credit due to some reasons such as lack of collateral, lack of account of operation, lack of bank relationship. while the result of inflation emphasized the importance of 
inflation in an economy. This means a little inflation is needed to increase profit and economic activities; however, it must be checked as it might have an adverse effect on the economy and activities of banks and businesses.

Findings of this study supported the theoretical framework as stipulated in this study as it postulated that monetary policy effect can be transmitted to an economy through interest rate which is more influenced by the monetary policy rate of the apex bank and this means, an increase in the MPR would automatically affect businesses. Empirically, this study supported the findings of the following in the long run Isola and Messagan (2018) who found negative effects of monetary policy on SMEs performance in Nigeria, Ghana and Gambia because of an increase in interest rate because of monetary policy. Same was the findings of Nto et al. (2012) as they also found negative effects of interest rate on credit supplied to SMEs in Nigeria. Although, few studies are available on the subject because most of the studies focus on government policies effect on SMEs' performance.

The study also supported the findings of Akinyemi and Adejumo (2015), Biljana and Tamara (2013), Kolawole and Lucky (2018) in the short run as they found a positive effect of monetary policy on SME's performance. It was also to support Mordi et al., (2014) as they found that consolidation exercise of banks affected the growth of credit to SMEs negatively as the value of credit delivered after consolidation decreased by 60.48 percent from N62 billion to N24.5 billion during the period under review. This summary of findings supported both the negative and positive effect of monetary policy because when MPR is increased the effect may be negative and when it is reduced it may be positive.

\section{Conclusion and Recommendations}

Having examined the effect of monetary policy on credit supply to small and medium-scale enterprises in Nigeria, the study concluded that monetary policy has heterogeneous effects on credit supply to SMEs through the lending rate of commercial banks in

Nigeria. Hence, the study recommends that, as the central bank continues to implement monetary policy in Nigeria, caution should be taken so that such decisions won't affect businesses such as SMEs. In addition, the MPR should be further reviewed downward to encourage SMEs from assessing funds. Likewise, financial institutions should increase the percentage of their credits to 
SMEs to reduce the financing gap and enhance their performance for the betterment of the Nigerian economy. Likewise, the central bank should create a pool of long-term funds to bridge the financing gap of SMEs in Nigeria. Lastly, there should be fewer restrictions for SMEs to assess bank loans by easing the documentation for loan processes among banks in Nigeria.

\section{DECLARATIONS}

Ethics approval and consent to participate

Not applicable

\section{Consent for publication}

Not applicable

\section{Availability of data and materials}

The time-series data for this research were sourced from the Central Bank of Nigeria (CBN) statistical bulletin of various editions, covering 2000 to 2018.

\section{Competing interests}

The authors declare no competing interests.

\section{Funding}

Not applicable

\section{Authors' contributions}

$\mathrm{CO}$ performed the review of articles, fashioned out the methodology and carried out the discussion of findings of this study. AT analysed, interpreted the results emanating from the study and also did the content editing

\section{Acknowledgments}

Not applicable

\section{Authors' Information}

$\mathrm{CO}$ holds a PhD in Finance. He is currently a Lecturer 1 at Afe Babalola University, Ado-Ekiti, Ekiti State, Nigeria. AT holds a $\mathrm{PhD}$ in Finance. He is currently a Senior Lecturer and the Director of Information Technology at Afe Babalola University, Ado-Ekiti, Ekiti State, Nigeria. 


\section{References}

Ajisafe, R. A., \& Folorunso, B. A. (2002). The relative effectiveness of monetary policy in macroeconomic management in Nigeria. The African Economic \& Business Review, 3(1), $23-40$.

Alexander, R., Balino, A. \& Enoma, S. (1996). Economic sustainability and the role of fiscal and monetary policies in a depressed economy: The case study of Nigeria. Sustainable Development, 3(1), 89-100.

Akawu, F.A., Agum, C., \& Olarenwaju, A.P. (2018). Impact of government support on small and medium enterprises (SMEs) development in Nasarawa State. International Journal of Advanced Research in Public Policy, Administration and Development Strategies, 3(1), 90-105

Akinyemi, F.O., \& Adejumo, O.O. (2018). Government policies and entrepreneurship phases in emerging economies: Nigeria and South Africa. Journal of Global Entrepreneurship Research, 8(35), 1-18

Aminu, B., Adamu, J., \& Ibrahim, A. (2018). Impact of small and medium scale enterprises on economic growth of Nigeria. Global Journal of Economics and Business, 4(2), 236 - 244.

Asa-Afiana, S. (2003). Monetary policy and macroeconomic instability in Nigeria. Journal of Social Sciences, 12(2), 93-100.

Atarere, J.W. (2016). The influence of monetary and fiscal actions on total spending: The St. Louis total spending equation revisited. Journal of Money Credit and Banking, 7(2), 181-192.

Ayodeji, E.A., \& Ajala, R.B. (2018). Market based monetary policy instruments and industrial growth in Nigeria (1993-2016). International Journal of Innovative Research \& Development, 7(8), 387-396

Berger, A., \& Udell, G. (2002). Small business credit availability and relationship lending: The importance of bank organizational structure. Washington D. C: Federal Reserve Board Working Paper.

Biljana, R., \& Tamara, R. (2013). The effectiveness of monetary and fiscal policy in Serbia. Industrija, 41(2), 103-123.

Chingarande, A. (2013). The relative effectiveness of Monetary and Fiscal policies on economic activity in Zimbabwe (1981:4-1998: 3): An error correction approach. International Journal of Management Sciences and Business Research, 1(5), 1-35. 
Duru M. \& Kehinde L. M (2012). Financial sector reforms and the growth of small and medium scale enterprises (SMEs in Nigeria. Universal Journal of Management and Social Sciences, 2(8), 9-16.

Ezeji, C., \& Michael, N. (2013). The impact of monetary and fiscal policies on Nigerian economic growth: 1990-2010. European Journal of Business and Management, 5(2), $13-26$.

Folawewo, A., \& Osinubi, T. (2006). Monetary policy and macroeconomic instability in Nigeria: A rational expectation approach. Journal of Social Sciences, 12(2), 93-100.

Gbandi, E. C. \& Amissah, G (2014). Financing options for small and medium enterprises (SMEs) in Nigeria. European Scientific Journal, 10(1), 1857 - 7881.

Imoisi, A.I., \& Jumbo, E. (2011). Small and Medium scale enterprises and economic growth in Nigeria: 1975-2012. International Journal of Business and Management. 10(3), 205-215

Imoughele, L. E., \& Ismaila, M. (2014). The impact of commercial bank credit on the growth of small and medium scale enterprises: An econometric evidence from Nigeria (1986-2012). Journal of Educational Policy and entrepreneurial Research (JEPER), 1(2), 44 -56.

Isola, W.A., \& Mesagan (2018). Monetary policy and small and medium enterprises' performance in selected West African countries. The Romanian Economic Journal, 21(69), 14-23.

Jawaid, S., Arif, I. \& Naeemullah, S. (2010). Comparative analysis of monetary and fiscal policy: A case study of Pakistan. NICE Research Journal, 3(1), 58-67.

Kahn, I. (2010). Small and medium scale enterprises and employment generation in Nigeria: The role of Finance. Kuwait Chapter of Arabian Journal of Business and Management Review, 1(9), 79-94.

Kolawole, A., \& Lucky, D. (2018). Impact of monetary policy on small scale enterprises financing in Nigeria. International Journal of Small and Medium Enterprises, 1(2), 1-12

Mishkin, D. (2007). The relative impact of fiscal versus monetary actions on output: A vector autoregressive (VAR) approach. Business \& Economic Journal, 25(1), 1 - 11.

Mordi, C.N.O., Anyanwu, C.M., Adebusuyi, B.S., Odey, L.I., Amoo, B.A.G., Mbutor, O.M., Adebayo, O., Akpan, N.I. (2014). Credit delivery to small and medium enterprises: Post Bank Consolidation in Nigeria. Central Bank of Nigeria, Occasion paper, No.53 
Motilewa, B.D., Ogbari, M., \& Aka, D.O. (2015). A review of the impacts of SMEs as a social agent for economic liberations in developing economies. International Review of management and Business Research, 4(3), 903-914

Mustar, C. (2002). Monetary and fiscal policy shocks and economic growth in Kenya: VAR econometric approach, Journal of World Economic Research, 2(6), 95-108.

Nto, O.O., Mbanasor,J.A., \& Osuala, A.E. (2012). Influence of monetary policy variables on loan supply to small and medium scale enterprises in Nigeria. International Journal of Economics and Finance, 4(7), 157-164

Ogechukwu, A. (2009). Does monetary policy influence economic growth in Nigeria? Asian Economic and Financial Review, 3(5), 635-646.

Onugu, O. (2005). Bank management: Principles and practice, Ikeja: Malthouse Press Ltd.

Oyeniran, I.W., David, O.O., \& Ajayi, O. (2015). SMEs and economic growth in Nigeria: An autoregressive distributed lag approach. The Lahore Journal of Business, 3(2), 1-16

Sanni, M. R., Amusa, N. A., \& Agbeyangi, B. A. (2012). Potency of monetary and fiscal policy instruments on economic activities of Nigeria (1960-2011). Journal of African Macroeconomic Review, 3(2), 161-176.

Udoh, F.S., Gbande, C., \& Acha, I.A. (2018). Monetary policy and growth of small and medium enterprises in Nigeria. International Journal of Advanced Studies in Business Strategies and Management, 6(1), 39-60

Uniamikogbo, A. \& Enoma, R. (2001). Monetary and fiscal impacts on economic activities in Bangladesh: A note. The Bangladesh Development Studies, 14(2), 101-106.

Younus, M. A. (2012. A survey of government industrial policy and programmes on SME growth and entrepreneur's development strategy in Nigeria. Atlanta: Prentice Hall, Inc.

Yahaya, H.D., Geidama, M.M., \& Usman, M.U. (2016). The role of micro small and medium enterprises in the economic development of Nigeria. International Journal of Small Business and Entrepreneurship Research, 4(3), 33-47 